\title{
Chemical composition and release rate of waste discharge from an Atlantic salmon farm with an evaluation of IMTA feasibility
}

\author{
Xinxin Wang ${ }^{1, *}$, Kjersti Andresen ${ }^{1}$, Aleksander Handå ${ }^{2}$, Bjørn Jensen $^{3}$, \\ Kjell Inge Reitan ${ }^{1}$, Yngvar Olsen ${ }^{1}$ \\ ${ }^{1}$ Trondheim Biological Station, Department of Biology, Norwegian University of Science and Technology, 7491 Trondheim, \\ Norway \\ ${ }^{2}$ SINTEF Fisheries and Aquaculture, 7465 Trondheim, Norway \\ ${ }^{3}$ Lerøy-Midnor, 7247 Hestvika, Norway
}

\begin{abstract}
The carbon $(\mathrm{C})$, nitrogen $(\mathrm{N})$ and phosphorus $(\mathrm{P})$ compositions of salmon feed, fish and faeces were studied at a salmon farm in Badstuvika $\left(63^{\circ} 31^{\prime} \mathrm{N}, 9^{\circ} 9^{\prime} \mathrm{E}\right)$ in central Norway. These data were used to estimate the release rates of wastes from 2 salmon cages and the qualities of particulate wastes as food resources for integrated multi-trophic aquaculture (IMTA). About $38 \%$ of feed $\mathrm{C}, 43 \%$ of feed $\mathrm{N}$ and $24 \%$ of feed $\mathrm{P}$ were retained as fish biomass. About $62 \%$ of feed C, $57 \%$ of feed $\mathrm{N}$ and $76 \%$ of feed P were lost into the environment. Around $40 \%$ of feed $\mathrm{C}$ was respired as $\mathrm{CO}_{2}$, and $39 \%$ of feed $\mathrm{N}$ and $24 \%$ of feed $\mathrm{P}$ were excreted as dissolved inorganic nitrogen and phosphorus, respectively. About $19 \%$ of feed C, $15 \%$ of feed $\mathrm{N}$ and $44 \%$ of feed P were released as particles. The chemical composition of feed was independent of time $(p>0.05)$. The faecal $\mathrm{C}$ content increased with increasing fish weight $\left(\mathrm{r}^{2}=0.14, \mathrm{p}<0.05\right)$; however, other faecal chemical components showed no apparent relationships with fish weight $(p>0.05)$. Our results suggested that P digestibility of feed may be $30 \%$, but more information is still needed to reach conclusions on this. The $\mathrm{C}$ content of faeces was $70 \%$ of that of feed and the $\mathrm{N}$ content of faeces was $50 \%$ of that of feed. The P content was far higher than that of feed. The lipid, docosahexaenoic acid and eicosapentaenoic acid contents of faeces were comparable to those of some phytoplankton species. The results suggested that both feed and faeces are adequate food for blue mussels and sea cucumbers co-cultured with salmon, and the nutrient content may meet their nutritional requirements.
\end{abstract}

KEY WORDS: Mass balance - Chemical composition · Faeces · Integrated multi-trophic aquaculture $\cdot$ Salmon farming $\cdot$ Salmo salar

\section{INTRODUCTION}

Aquaculture is growing quickly with an average global growth rate of $6.3 \%$ per year, and further growth is expected (FAO 2012). Norwegian aquaculture has expanded rapidly during recent decades and has become a well-established industry (Skogen et al. 2009). Norway has increased its aquaculture production from 0.15 million tonnes in 1990 to 1.01

*Email: Xinxin.Wang@bio.ntnu.no million tonnes in 2010, and has become the world's largest producer of farmed Atlantic salmon (FAO 2012).

During intensive production of salmon in open cages, the discharges of organic wastes such as faeces and uneaten feed and inorganic nutrients such as ammonium $\left(\mathrm{NH}_{4}^{+}\right)$and phosphate $\left(\mathrm{PO}_{4}{ }^{-3}\right)$ are released directly into the environment and may cause negative ecological effects on the surrounding

(C) The authors 2013. Open Access under Creative Commons by Attribution Licence. Use, distribution and reproduction are unrestricted. Authors and original publication must be credited. 
waters (Merceron et al. 2002, Carroll et al. 2003, Cheshuk et al. 2003, Skogen et al. 2009, MacDonald et al. 2011). Particulate organic matter may accumulate in the sediments and cause changes in the benthic ecosystem (Carroll et al. 2003, Stigebrandt et al. 2004, Kutti et al. 2007, 2008). The enrichment of inorganic nutrients in the water column may cause eutrophication (Hall et al. 1990, Cloern 2001, Mantzavrakos et al. 2005, Skogen et al. 2009). The release rates of wastes from Norwegian salmon aquaculture was closely related to the feed used, and the $\mathrm{C}, \mathrm{N}$ and $\mathrm{P}$ wastes in 2009 were estimated to be $70 \%$ of feed $\mathrm{C}, 62 \%$ of feed $\mathrm{N}$ and $70 \%$ of feed $\mathrm{P}$, corresponding to $404 \mathrm{kt} \mathrm{C}, 51 \mathrm{kt} \mathrm{N}$ and $9.4 \mathrm{kt} \mathrm{P}$ per year. Of the total emissions, about $109 \mathrm{kt} \mathrm{C}, 12 \mathrm{kt} \mathrm{N}$ and 5.9 kt $\mathrm{P}$ were associated with faeces and feed particles, whereas about $36 \mathrm{kt} \mathrm{N}$ and $2.5 \mathrm{kt} \mathrm{P}$ were released as dissolved inorganic nutrients (Wang et al. 2012).

The salmon farms in Norway are now mainly situated in relatively exposed waters with high rates of water exchange (Skogen et al. 2009), but there may still be negative environmental effects of aquaculturederived wastes if the emission rates are too high relative to the assimilation capacity of the receiving waters.

The environmental influence of aquaculture-derived wastes has caused public concerns. Minimising aquaculture discharge is important in mitigating potential environmental problems and thereby contributing to environmentally sustainable production (Hall et al. 1990, Bureau et al. 2003). This has been mediated through the optimisation of feeding technology and feed ingredients, resulting in a better feed conversion ratio (FCR; dry feed per wet fish produced) that has been reduced from 1.7 in 1993 (Reid et al. 2009) to $<1.2$ in recent years (Bureau et al. 2003, Wang et al. 2012). These improvements have reduced the release rates of organic and inorganic wastes per unit of fish produced to a great extent (Cheshuk et al. 2003, Islam 2005).

Integrated multi-trophic aquaculture (IMTA) has been suggested as a promising means to mitigate any negative ecological effects of fish farming utilising fish wastes as food resources for extractive species at lower trophic levels (Cheshuk et al. 2003). In such IMTA systems, macroalgae can be cultured close to fish cages to remove soluble inorganic nutrients such as ammonia and phosphate, which are excreted by fish (Buschmann et al. 1996, Petrell \& Alie 1996, Chopin et al. 2001, Porrello et al. 2003, Zhou et al. 2006, Marinho-Soriano et al. 2009, Abreu et al. 2011). Filter-feeding species, such as blue mussels, cultured adjacent to fish cages may consume small particulate wastes (Troell \& Norberg 1998, Cheshuk et al. 2003, Whitmarsh et al. 2006), as well as phytoplankton stimulated by inorganic nutrients excreted by fish (Handå 2012). The potential for mussel production that was based on particulate wastes, however, was far lower than for seaweed because of fewer initial available resources and the metabolic losses of mussels (Wang et al. 2012). Most of the particles originating from fish faeces or uneaten feed may sediment out near the cages (Elberizon \& Kelly 1998); such wastes may be better utilised by co-cultured depositfeeding species, for example sea cucumbers, and the nutritional value of the particle wastes released from fish farming should be more closely evaluated (Grémare et al. 1997, Ahlgren 1998, Ren et al. 2012).

The qualities of the biogenic wastes as food resources in IMTA are important, together with quantitative knowledge on the release rates (Bureau et al. 2003). The release rates and $\mathrm{C}: \mathrm{N}: \mathrm{P}$ ratios of the wastes on a Norwegian national scale have been estimated using a mass balance model by Wang et al. (2012) with coefficients taken from the literature. The objective of the present study was to revise some of the coefficients in the mass balance model (Wang et al. 2012) to better describe the release rates of the wastes from salmon farming. This was accomplished by determining the $\mathrm{C}, \mathrm{N}$ and $\mathrm{P}$ compositions of feed, fish and faeces from a salmon farm in central Norway. We then used the mass balance model with the revised coefficients to estimate the release rates of the wastes from the salmon farm, with a main focus on particulate wastes and their qualities as food resources for IMTA.

\section{MATERIALS AND METHODS}

\section{Study site description}

The study was carried out at a commercial salmon farm with second-year fish located at Badstuvika $\left(63^{\circ} 31^{\prime} \mathrm{N}, 9^{\circ} 9^{\prime} \mathrm{E}\right)$ in central Norway in 2009 . The site held 8 circular net cages arranged in 2 parallel rows and each cage had a circumference of $157 \mathrm{~m}$ and a net depth of $18 \mathrm{~m}$. The annual production was $4442 \mathrm{t}$. The current speed of the water at surface, 5 and $10 \mathrm{~m}$ depth at the farm location generally was between 0 and $0.25 \mathrm{~m} \mathrm{~s}^{-1}$ in May.

The study included 2 cages (Cage S and Cage L). The experiment was carried out from March to November for Cage S, and from March to July for Cage L. The wet weight and length of the sampled fish, and the amount of feed used and fish produced 
Table 1. Wet weight and length of fish samples from Cage S and Cage L, as well as the total amount of feed used and production for these 2 cages in 2009

\begin{tabular}{|lcc|}
\hline & $\begin{array}{c}\text { Cage S } \\
\text { March-November }\end{array}$ & $\begin{array}{c}\text { Cage L } \\
\text { March-July }\end{array}$ \\
\hline Fish wet weight (kg) & $1.2-5.2$ & $2.1-4.8$ \\
Fish length (cm) & $47-75$ & $54-75$ \\
Feed used (t) & 602 & 393 \\
Production (t) & 548 & 353 \\
\hline
\end{tabular}

for 2 cages are shown in Table 1. Dead fish were removed from the pens daily, and were weighed and then destroyed.

\section{Sampling procedures}

Feed samples

Approximately $500 \mathrm{~g}$ of feed sample was collected on each sampling day, and a total of 8 feed samples were collected throughout the experimental period. The feed samples were transported to the laboratory and kept in darkness at $-20^{\circ} \mathrm{C}$ until further analysis.

\section{Fish and faeces samples}

Six fish (3 individual fish from each cage) were randomly caught monthly for determination of chemical composition of fish whole-body tissue and faeces. Fish were caught using a grab net and thereafter killed by a blow to the head. The fish were thereafter dissected and faeces samples were taken from the latter half of the hindgut to avoid contamination by urine. The sample was immediately frozen on dry ice $\left(\mathrm{CO}_{2}\right)$. The gut was washed in seawater to remove the rest of the gut content and thereafter put back into the fish. Fish and faeces samples were brought back to the laboratory and kept in darkness at $-20^{\circ} \mathrm{C}$ before further processing.

In the laboratory, the frozen fish samples were allowed to thaw, chopped into approximately $0.5 \mathrm{~kg}$ pieces, and were thereafter ground into homogeneous slurry. Subsamples were transferred to $50 \mathrm{ml}$ centrifuge tubes, flushed with nitrogen gas and stored in darkness at $-80^{\circ} \mathrm{C}$ for further analysis.

These subsamples, together with faecal samples, were freeze-dried (HMS-DATABLAD GP-030) for $3 \mathrm{~d}$ to a constant weight, ground in a coffee bean grinder for $3 \mathrm{~min}$, transferred to $50 \mathrm{ml}$ centrifuge tubes and stored in darkness at $-80^{\circ} \mathrm{C}$ until analysis. Moisture content was calculated by weighing the samples before and after freeze-drying.

\section{Chemical analysis of feed, fish and faeces}

The C and N contents of freeze-dried feed, fish whole-body tissue and faeces were determined in an elemental combustion system (Costech Analytical Technologies), using 3 to 4 replicates for each sample. The P contents of feed, fish whole-body tissue and faeces were determined in 3 replicates after oxidation of the sample in sulphuric acid and oxidizing reagent (potassium peroxidisulphate) for $30 \mathrm{~min}$ at $120^{\circ} \mathrm{C}$ (Hansen \& Koroleff 1999).

The total lipid and fatty acid compositions of feed, fish whole body tissue and faeces were extracted according to the method of Bligh \& Dyer (1959). Fatty acid methyl esters were prepared according to Metcalfe et al. (1966) and analysed with a gas chromatograph (Perkin Elmer AutoSystem XL) using the software TotalChrom V.6.3.1 (Perkin Elmer) (Bergvik et al. 2012).

\section{Mass balance model of $\mathbf{C}, \mathbf{N}$ and $\mathbf{P}$}

A mass balance model was used to estimate the release rates of particulate and dissolved $\mathrm{C}, \mathrm{N}$ and $\mathrm{P}$ wastes from Cage $S$ and Cage L. When feed $(C, N$ and $\mathrm{P}$ ) is given to a salmon cage, it is either consumed by the fish or lost as uneaten feed. A proportion of the consumed feed $\mathrm{C}, \mathrm{N}$ and $\mathrm{P}$ is digested, and used for growth, respired as $\mathrm{CO}_{2}$ or excreted as dissolved inorganic nitrogen (DIN) and phosphorus (DIP). The consumed feed $\mathrm{C}, \mathrm{N}$ and $\mathrm{P}$ that are not digested by the fish will be released in faeces. The feed $\mathrm{C}, \mathrm{N}$ and $\mathrm{P}$ lost in uneaten feed and faeces are referred to as particulate organic carbon (POC), nitrogen (PON) and phosphorus (POP). A fraction of the uneaten feed and faeces will dissolve and become dissolved organic carbon (DOC), nitrogen (DON) and phosphorus (DOP) (Wang et al. 2012).

The model coefficients measured in the present study were used to provide more adequate predictions of the release rates. These coefficients included measurements of dry matter content and $\mathrm{C}, \mathrm{N}$ and $\mathrm{P}$ stoichiometry of feed and fish.

The data on the feed used and fish produced per month for Cage S and Cage L were made available by the fish farmers. Further required data on the digestibility of $\mathrm{C}, \mathrm{N}$ and $\mathrm{P}$ in feed were taken from published data and feed producers (Wang et al. 




Fig. 1. Feed used (dry weight) and fish produced (wet weight) in 2 salmon cages - (A) Cage S and (b) Cage L - in Badstuvika during the experimental periods in 2009. Feed used and production values were provided by the fish farm in Badstuvika, fish were slaughtered in July in Cage S and in October in Cage L

2012). The rate of feed losses was taken from fish farmers and published data (Cromey et al. 2002, Reid et al. 2009, Wang et al. 2012).

\section{Data analysis}

Data for monthly chemical composition of feed, fish and faeces were tested for normality using the Kolmogorov-Smirnov test, and for homogeneity of variance using Levene's test. The equality of means for chemical content of feed, fish and faeces between months was tested using a one-way ANOVA followed by a Tukey's honestly significant difference (HSD) post hoc comparison. The equality of means for model predicted and measured C:N:P ratios was tested using the independent-samples $t$-test. The correlations between FCR and fish wet weight and between growth efficiency (GE) and fish weight were examined by regression. The correlations between chemical content of feed and day of year, between chemical content of fish whole-body tissue and fish wet weight, and between chemical content of faeces and fish wet weight were examined by regression. Statistical analyses were performed using PASW Statistics 18. The regressions were carried out using SigmaPlot 10.0. The regression curves were determined by choosing the best $\mathrm{R}^{2}$ values. The significance limits were set at 0.05 and the means are presented $\pm \mathrm{SE}$.

\section{RESULTS}

\section{Growth and feed used}

The water temperature ranged between $5.9^{\circ} \mathrm{C}$ in March and $14^{\circ} \mathrm{C}$ in September, with a mean value of $10 \pm 1{ }^{\circ} \mathrm{C}$ during the experimental periods. The oxygen saturation decreased from $96 \%$ in May to $77 \%$ in September, where after it levelled off (data not shown).

The monthly feed used and the fish produced (growth in biomass) (Fig. 1) varied with time during the experimental period in both cages, with the highest values in September for Cage $\mathrm{S}$ and in June for Cage L. The reductions in feeding and production were mainly a result of harvesting. The feed used and fish produced for Cage S from March to October were higher than for Cage L from March to July (Table 1). This was a result of different fish biomass and growth stages in the 2 cages.

The FCR was calculated as dry weight feed supplied per wet weight fish produced and showed mean values of $1.08 \pm 0.02$ and $1.11 \pm 0.02$, respectively, for Cage $\mathrm{S}$ and Cage L, suggesting that larger fish may have lower production yields per feed input than smaller fish (Fig. 2A).

The GE in terms of $\mathrm{C}, \mathrm{N}$ and $\mathrm{P}$ (estimated as fish $\mathrm{C}$, $\mathrm{N}$ and $\mathrm{P}$ produced per $\mathrm{C}, \mathrm{N}$ or $\mathrm{P}$ consumed, respectively) showed a slight decrease with time in both cages (Fig. 2B). The overall $\mathrm{GE}_{\mathrm{P}}$ was lower throughout than $\mathrm{GE}_{\mathrm{C}}$, whereas $\mathrm{GE}_{\mathrm{N}}$ was higher, indicating lower GE of feed $\mathrm{P}$ and higher GE of feed $\mathrm{N}$ in comparison to feed $\mathrm{C}$. On average, $40 \pm 0.6 \%$ of the eaten $\mathrm{C}, 46 \pm 0.7 \%$ of the eaten $\mathrm{N}$ and $26 \pm 0.4 \%$ of the eaten $\mathrm{P}$ were retained as fish biomass for Cage $\mathrm{S}$. For Cage L, $39 \pm 0.6 \%$ of the eaten C, $43 \pm 0.6 \%$ of the eaten $\mathrm{N}$ and $24 \pm 0.4 \%$ of the eaten $\mathrm{P}$ were retained as fish biomass.

FCRs for both cages were equally and significantly positively correlated to fish wet weight $(p<0.05$; Fig. 3A), whereas GE in terms of $\mathrm{C}, \mathrm{N}$ and $\mathrm{P}$ were equally and significantly inversely related to fish wet weight ( $p<0.05$; Fig. 3B). 

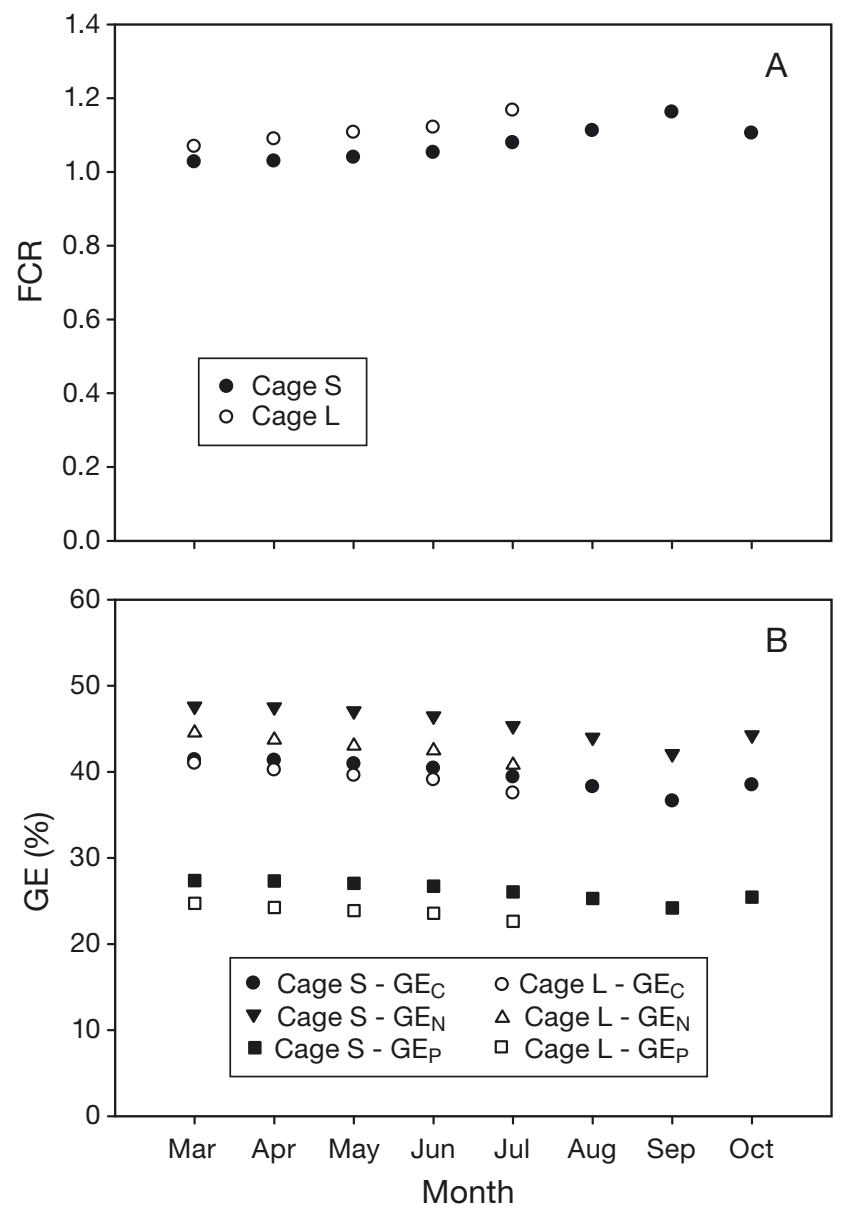

Fig. 2. (A) Feed conversion ratio (FCR) and (B) growth efficiency (GE) of $\mathrm{C}, \mathrm{N}$ and $\mathrm{P}$ for Cage $\mathrm{S}$ and Cage $\mathrm{L}$ for each month. FCR was expressed in terms of feed use (dry weight) per fish produced (wet weight). GE was estimated for $\mathrm{C}, \mathrm{N}$ and $\mathrm{P}$ and was expressed as fish $\mathrm{C}, \mathrm{N}$ and $\mathrm{P}$ produced per $\mathrm{C}$, $\mathrm{N}$ and $\mathrm{P}$ consumed, respectively

\section{Chemical composition}

Feed

The dry matter content of feed was in the range of 97 to $99 \%$ of wet weight, with a mean of $98 \pm 0.1 \%$ ( $\mathrm{n}=23$ ). The chemical composition of feed over the sampling period and the regression coefficients for chemical content as functions of time (day of year) are summarized in Table 2. There were no significant relationships between the chemical content of feed and time ( $p>0.05$ for all variables; Table 2). However, there were small significant variations in the contents of $\mathrm{C}$, lipid, N, docosahexaenoic acid (DHA) and eicosapentaenoic acid (EPA) and percentages of DHA and EPA in the total fatty acid (TFA) content of feed (ANOVA, p < 0.05), while no significant differences were found in $\mathrm{P}$ content of feed (ANOVA, $\mathrm{p}>$
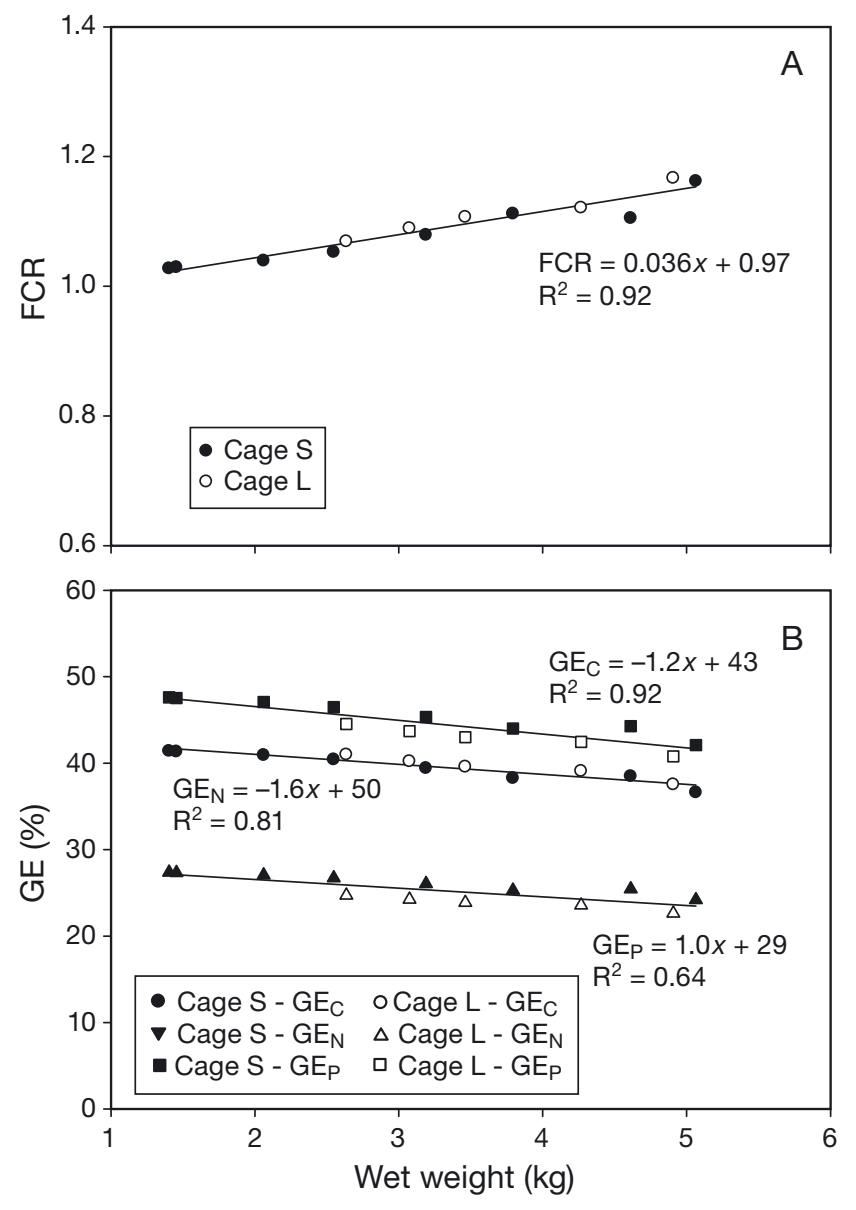

Fig. 3. (A) Relationship between feed conversion ratio (FCR) and fish wet weight. (B) Relationship between growth efficiencies (GE of $\mathrm{C}, \mathrm{N}$ and $\mathrm{P}$ ) and fish wet weight. Fish were sampled from Cage $\mathrm{S}$ and Cage $\mathrm{L}(\mathrm{n}=13)$. Solid lines are regression lines

0.05; Fig. 4). The chemical compositions of feed were therefore concluded to be constant and independent of time. The mean values for $\mathrm{C}, \mathrm{N}$ and $\mathrm{P}$ contents of feed were therefore used as model input data.

The $\mathrm{N}: \mathrm{C}$ ratios of feed were in the range of 100 to $122 \mu \mathrm{g} \mathrm{N} \mathrm{mg}^{-1} \mathrm{C}\left(\right.$ mean $\left.=108 \pm 7.2 \mu \mathrm{g} \mathrm{N} \mathrm{mg}^{-1} \mathrm{C}\right)$, the $\mathrm{P}: \mathrm{C}$ ratios were in the range of 12 to $20 \mu \mathrm{g} \mathrm{P} \mathrm{mg}{ }^{-1} \mathrm{C}$ $\left(\right.$ mean $=17 \pm 2.7 \mu \mathrm{g} \mathrm{P} \mathrm{mg}^{-1} \mathrm{C}$ ) and the $\mathrm{N}: \mathrm{P}$ ratios were in the range of 5.8 to $9.2 \mathrm{mg} \mathrm{N} \mathrm{mg}^{-1} \mathrm{P}$ (mean $=6.6 \pm$ $1.2 \mathrm{mg} \mathrm{N} \mathrm{mg}^{-1} \mathrm{P}$ ).

Fish

The dry matter contents of fish whole body tissue were in the range of 31 to $40 \%$ of wet weight, with a mean value of $36 \pm 0.2 \%(n=96)$. The differences in chemical composition of fish whole-body tissue were 
Table 2. Range of chemical content and mean chemical content in feed samples from March to November 2009 (see Fig. 4 for the monthly chemical content), as well as regression coefficients (slope) for chemical content in feed samples as a function of time (day of year). DW: dry weight; DHA: docosahexaenoic acid; EPA: eicosapentaenoic acid; TFA: total fatty acids

\begin{tabular}{|c|c|c|c|c|c|c|c|}
\hline \multirow[t]{2}{*}{ Variable } & \multirow{2}{*}{\multicolumn{2}{|c|}{$\begin{array}{c}\text { Content } \\
\left(\mathrm{mg} \mathrm{g}^{-1} \mathrm{DW}\right)\end{array}$}} & \multirow{2}{*}{$\begin{array}{c}\text { Mean } \pm \text { SE } \\
\left(\mathrm{mg} \mathrm{g}^{-1} \mathrm{DW}\right)\end{array}$} & \multirow{2}{*}{\multicolumn{2}{|c|}{\begin{tabular}{cc}
\multicolumn{3}{c}{ Variable versus tim } \\
Slope $\pm \mathrm{SE}$ & $Y_{0} \pm \mathrm{SE}$ \\
$\left(\mathrm{mg} \mathrm{g}^{-1} \mathrm{DW} \mathrm{d} \mathrm{d}^{-1}\right)$ & $\left(\mathrm{mg} \mathrm{g}^{-1} \mathrm{DW}\right)$
\end{tabular}}} & \multirow[b]{2}{*}{$\mathrm{R}^{2}$} & \multirow[b]{2}{*}{$\mathrm{p}$} \\
\hline & & & & & & & \\
\hline $\mathrm{C}$ & 519 & 555 & $540 \pm 4$ & $-0.06 \pm 0.05$ & $551 \pm 7$ & 0.19 & 0.28 \\
\hline $\mathrm{N}$ & 55 & & $58 \pm 1$ & $-0.004 \pm 0.01$ & $58 \pm 2$ & 0.01 & 0.78 \\
\hline $\mathrm{P}$ & 6.4 & & $8.8 \pm 0.5$ & $0.006 \pm 0.01$ & $7.7 \pm 1.3$ & 0.12 & 0.40 \\
\hline Lipid & 355 & 418 & $385 \pm 7$ & $-0.007 \pm 0.01$ & $386 \pm 13$ & 0.001 & 0.95 \\
\hline DHA & & & $17 \pm 0.7$ & $0.001 \pm 0.01$ & $16 \pm 1$ & 0.002 & 0.92 \\
\hline \multirow[t]{2}{*}{ EPA } & 14 & & $19 \pm 0.8$ & $0.01 \pm 0.01$ & $17 \pm 2$ & 0.12 & 0.39 \\
\hline & \multicolumn{2}{|c|}{$\begin{array}{l}\text { Content } \\
(\%)\end{array}$} & $\begin{array}{lc}\text { ent } & \text { Mean } \pm \\
& (\%)\end{array}$ & $\begin{array}{l}\text { Slope } \pm \text { SE } \\
\left(\% d^{-1}\right)\end{array}$ & $\begin{array}{c}Y_{0} \pm \mathrm{SE} \\
(\%)\end{array}$ & & \\
\hline \multirow{2}{*}{\multicolumn{2}{|c|}{ DHA $\%$ of TFA }} & $4.6-$ & $5.4 \pm 0$ & $0.001 \pm 0.00$ & $5.3 \pm 0.5$ & 0.02 & 0.72 \\
\hline & & $4.7-$ & $6.1 \pm 0$ & $0.004 \pm 0.003$ & $3 \quad 5.6 \pm 0.4$ & 0.27 & 0.19 \\
\hline
\end{tabular}

tent. In Cage $\mathrm{L}$, the differences in $\mathrm{N}$, lipid and fatty acid (DHA and EPA) contents of fish wholebody tissue were significant among months (ANOVA, p < $0.05)$. The $C$ content was significantly different only between March and April (ANOVA, p < $0.05)$. The differences in percentages of DHA and EPA in TFA content were also significant (ANOVA, p < 0.05) while there were no differences in $\mathrm{P}$ content (ANOVA, p > 0.05) of fish whole-body tissue among months.

The proximate chemical compositions of fish whole body tissue and the regression coefficients for chemical contents as

small among months (Fig. 5). In Cage $\mathrm{S}$, the differences of $\mathrm{C}, \mathrm{N}, \mathrm{P}$, lipid and DHA and EPA contents were significant (ANOVA, $\mathrm{p}<0.05$ ), as was percentage EPA in TFA content, but no significant differences were found for percentage DHA in TFA con-
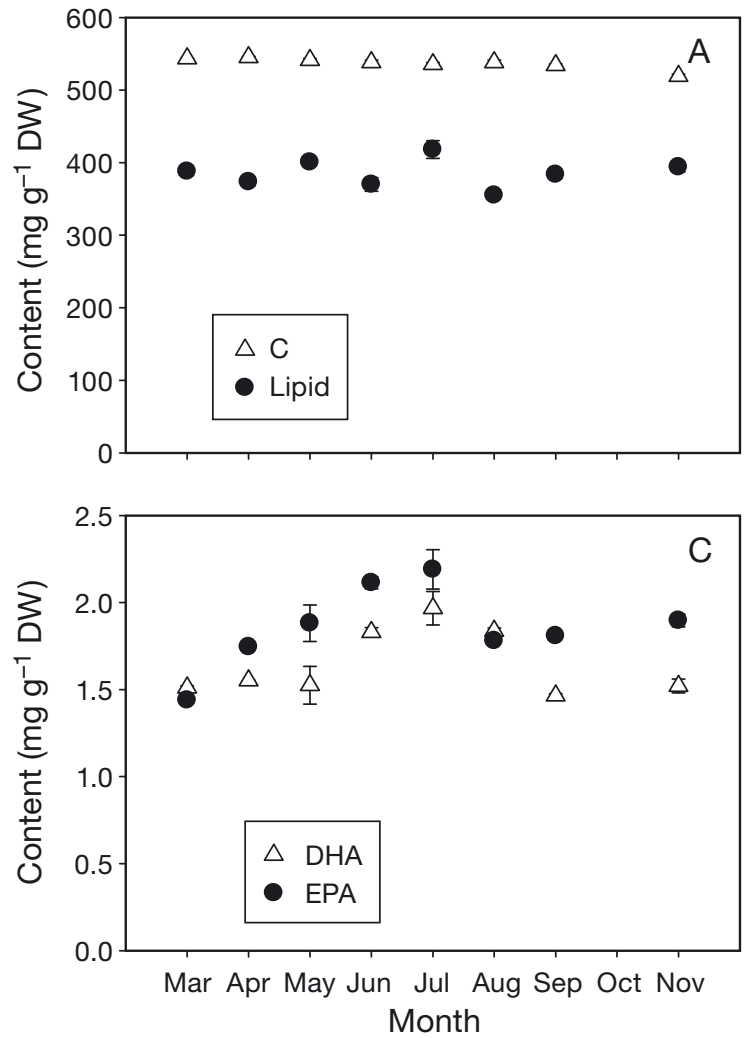

functions of fish wet weight $(\mathrm{kg})$ from Cage $\mathrm{S}$ and Cage $L$ are summarised in Table 3 . The C, lipid, DHA and EPA contents (Fig. 6A,D-F) of fish whole-body tissue increased significantly with fish wet weight ( $p<0.05$; Table 3 ) and showed hyperbolic relation-
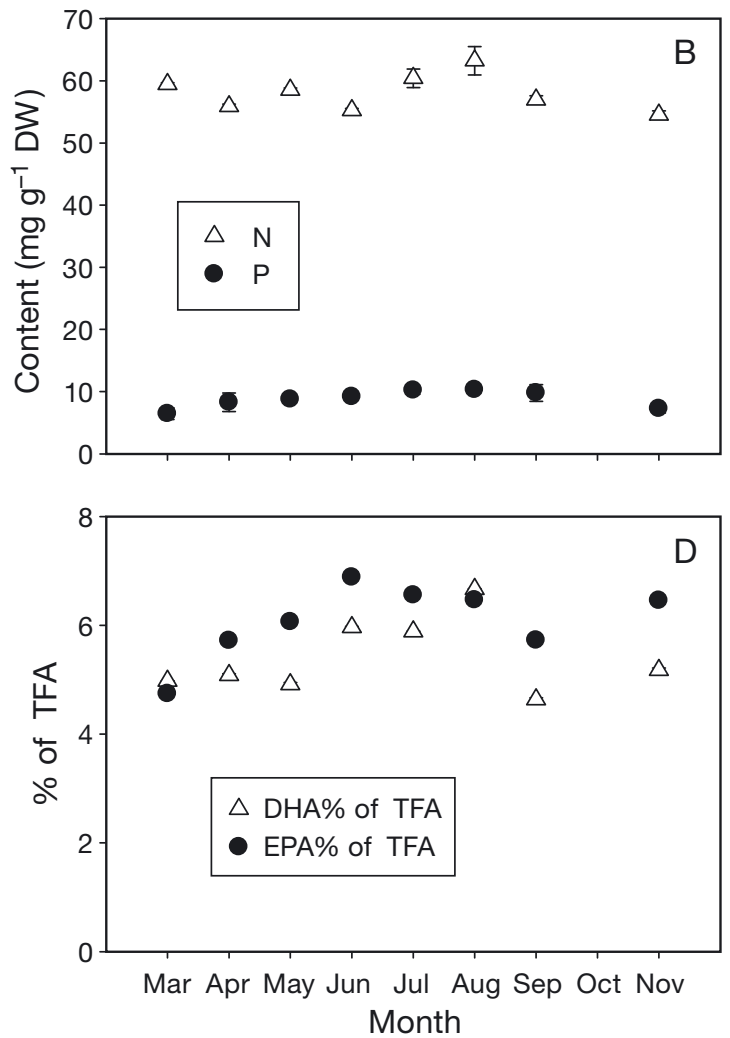

Fig. 4. Chemical contents per gram dry weight (DW) of feed used to feed Cage S and Cage L. (A) Carbon and lipid content; (B) nitrogen and phosphorus content; $(\mathrm{C})$ docosahexaenoic acid (DHA) and eicosapentaenoic acid (EPA) contents; and (D) percentage of DHA and EPA in total fatty acid (TFA) content. Error bars show $\pm 1 \mathrm{SE}$ 

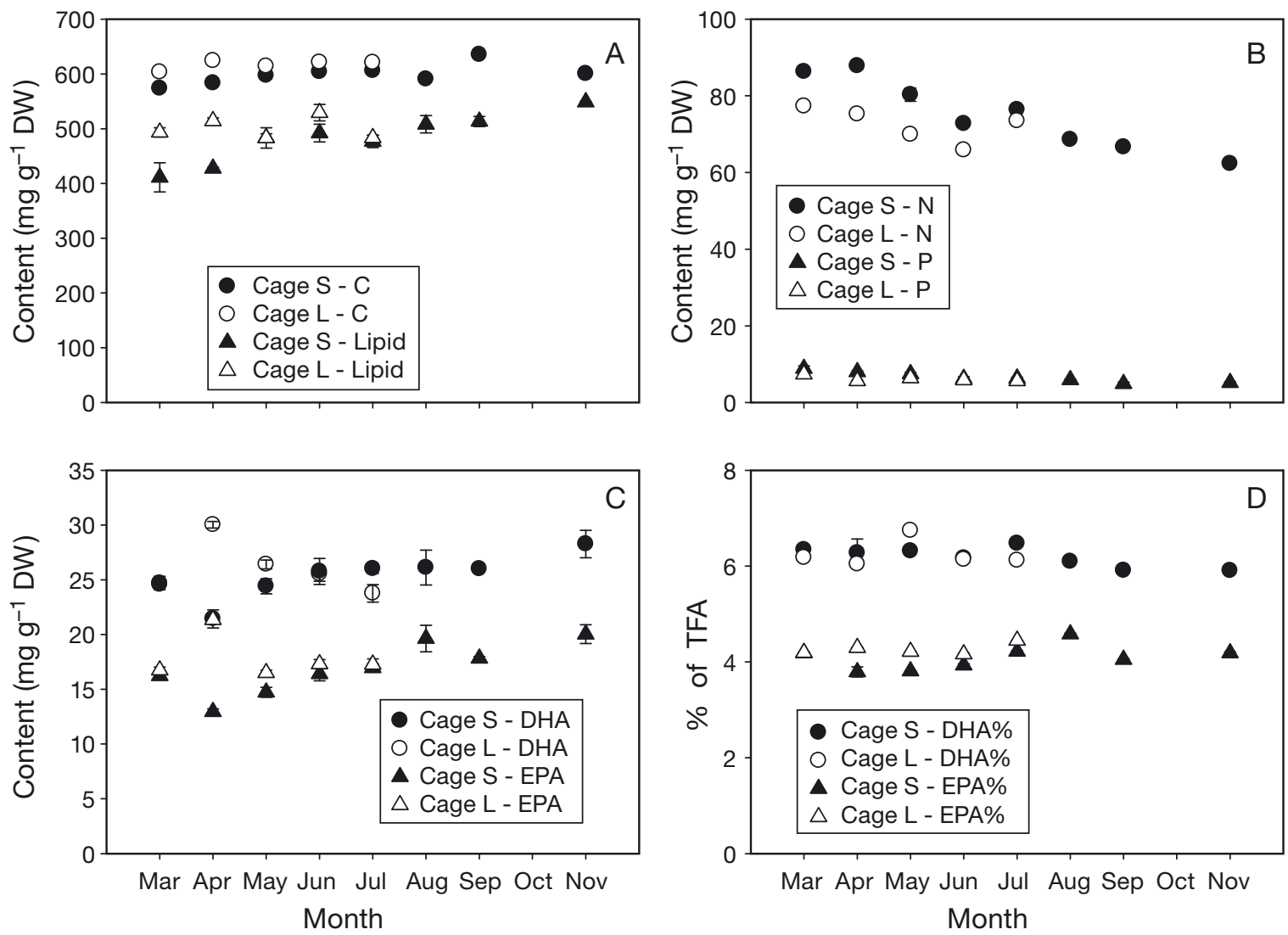

Fig. 5. Chemical contents per gram dry weight (DW) of fish body tissues sampled from Cage S and Cage L. (A) Carbon and lipid content; (B) nitrogen and phosphorus content; (C) docosahexaenoic acid (DHA) and eicosapentaenoic acid (EPA) content;

(D) percentage of DHA and EPA in total fatty acid (TFA) content. Error bars show $\pm 1 \mathrm{SE}$

Table 3. Range of chemical content and mean chemical content in fish samples from March to November 2009 (see Fig. 7 for the monthly chemical content for each cage), as well as $\mathrm{R}^{2}$ and $\mathrm{p}$-values for chemical content in fish samples as a function of fish wet weight $(\mathrm{kg})$. DW: dry weight; DHA: docosahexaenoic acid; EPA: eicosapentaenoic acid; TFA: total fatty acids

\begin{tabular}{|c|c|c|c|c|}
\hline \multirow[t]{2}{*}{ Variable } & \multirow[t]{2}{*}{$\begin{array}{c}\text { Content } \\
\left(\mathrm{mg} \mathrm{g}^{-1} \mathrm{DW}\right)\end{array}$} & \multirow[t]{2}{*}{$\begin{array}{c}\text { Mean } \pm \mathrm{SE} \\
\left(\mathrm{mg} \mathrm{g}^{-1} \mathrm{DW}\right)\end{array}$} & \multicolumn{2}{|c|}{$\begin{array}{c}\text { Variable versus } \\
\text { wet weight }\end{array}$} \\
\hline & & & $\mathrm{R}^{2}$ & $\mathrm{p}$ \\
\hline $\mathrm{C}$ & $574-635$ & $606 \pm 4.8$ & 0.63 & $<0.05$ \\
\hline $\mathrm{N}$ & $62-88$ & $74 \pm 2.1$ & 0.85 & $<0.05$ \\
\hline $\mathrm{P}$ & $4.9-8.9$ & $6.4 \pm 0.3$ & 0.62 & $<0.05$ \\
\hline Lipid & $411-549$ & $490 \pm 10$ & 0.84 & $<0.05$ \\
\hline DHA & $21-30$ & $26 \pm 0.6$ & 0.42 & $<0.05$ \\
\hline \multirow[t]{2}{*}{ EPA } & $13-20$ & $17 \pm 0.6$ & 0.43 & $<0.05$ \\
\hline & $\begin{array}{c}\text { Content } \\
(\%)\end{array}$ & $\begin{array}{c}\text { Mean } \pm \mathrm{SE} \\
(\%)\end{array}$ & & \\
\hline DHA $\%$ of TFA & 4.9-6.7 & $6.2 \pm 0.1$ & 0.28 & 0.12 \\
\hline EPA $\%$ of TFA & $3.8-4.6$ & $4.2 \pm 0.1$ & 0.12 & 0.33 \\
\hline
\end{tabular}

ships to fish wet weight, whereas $\mathrm{N}$ and $\mathrm{P}$ contents (Fig. 6B,C) exhibited inverse hyperbolic relationships with increasing fish wet weight ( $p<0.05$; Table 3$)$. The $C, N$, P, lipid, DHA and EPA contents of fish whole body tissue became constant for large individuals, which are in agreement with Moulton (1923). The percentages of DHA and EPA of TFA (Fig. 6G,H) in whole-body samples remained constant and independent of the fish wet weight $(p>0.05$; Table 3$)$. Similar trends were also observed for the relationships between chemical contents of fish whole-body tissue and fish length (data not shown).

Faeces

The dry matter content of faeces was in the range of 11 to $25 \%$ of wet weight with a mean of $15 \pm 0.6 \%$ $(\mathrm{n}=29)$. No differences were found in $\mathrm{P}$ content of faeces among different months for Cage S (ANOVA, p > 0.05; Fig. 7), while the other chemical components of faeces showed significant differences among 

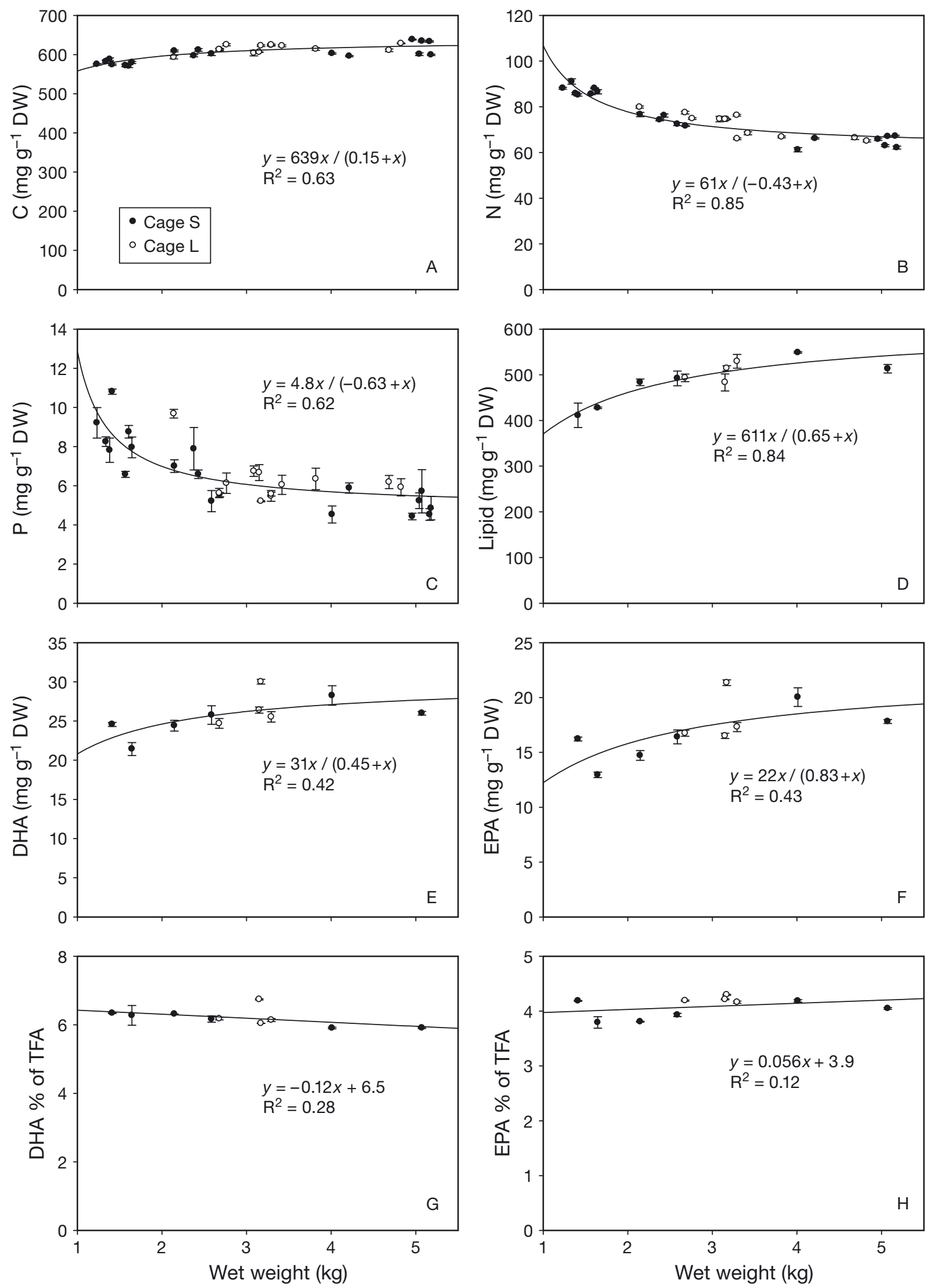

Fig. 6. Chemical contents per gram dry weight (DW) in fish whole-body samples from Cage S and Cage L in 2009 as a function of wet weight of individual fish. (A) Carbon; (B) nitrogen; (C) phosphorus; (D) lipid; (E) docosahexaenoic acid DHA; (F) eicosapentaenoic acid (EPA); (G) percentage of DHA in total fatty acid (TFA) content; and (H) percentage of EPA in TFA content. Error bars show $\pm 1 \mathrm{SE}$ 

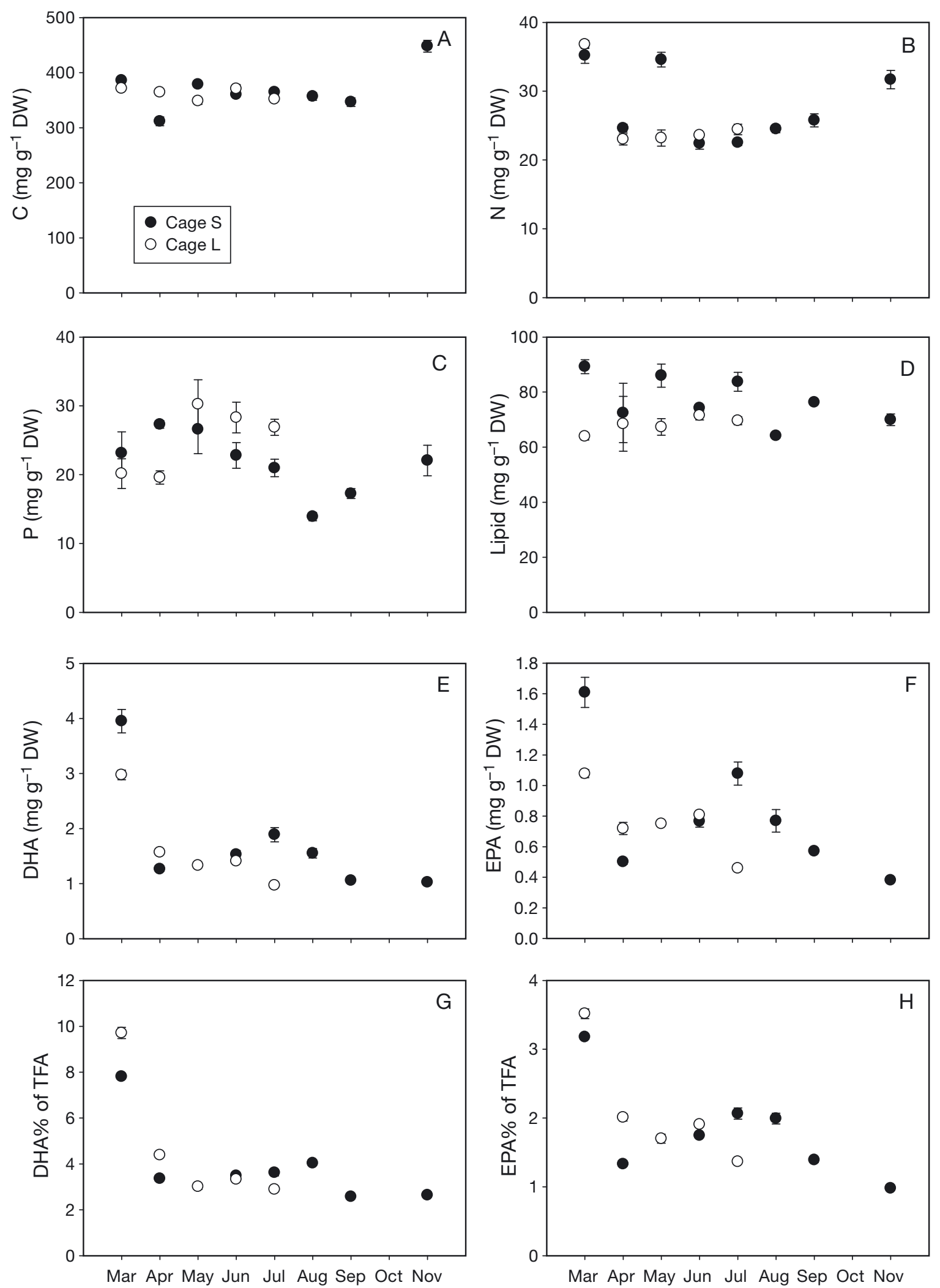

Month

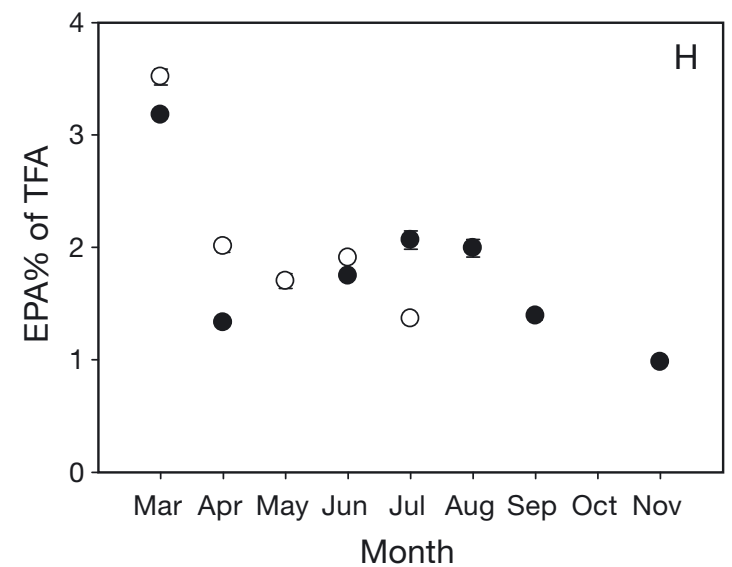

Fig. 7. Chemical contents per DW of faeces sampled from Cage S and Cage L. (A) Carbon; (B) nitrogen; (C) phosphorus; (D) lipid $_{i}(\mathrm{E})$ docosahexaenoic acid DHA $(\mathrm{F})$ eicosapentaenoic acid (EPA); (G) percentage of DHA in total fatty acid (TFA) content;

$(\mathrm{H})$ percentage of EPA in TFA content. Error bars show $\pm 1 \mathrm{SE}$ 
months (ANOVA, $\mathrm{p}<0.05$ ). For Cage $\mathrm{L}$, there were no significant differences in $\mathrm{C}, \mathrm{P}$ and lipid contents of faeces among months (ANOVA, p > 0.05), whereas the $\mathrm{N}$ content of faeces was significantly higher in March than in the other months (ANOVA, $\mathrm{p}<0.05$ ). The DHA and EPA contents showed significant differences among months, as did the percentages of DHA and EPA in TFA content of faeces (ANOVA, $p<$ 0.05 ). The lipid contents of faeces and fish were more variable than of feed throughout.

The $\mathrm{C}$ content of faeces showed a slight, although significant, increase with increasing fish wet weight $\left(r^{2}=0.14, p<0.05\right)$. However, other faecal chemical compositions showed no apparent relationships with fish wet weight (Table 4) and were accordingly independent of fish wet weight $(p>0.05)$.

The measured $\mathrm{N}: \mathrm{C}$ ratios of faeces varied between 62 and $99 \mu \mathrm{g} \mathrm{N} \mathrm{mg}{ }^{-1} \mathrm{C}$ (mean $=74 \pm 3.5 \mu \mathrm{g} \mathrm{N} \mathrm{mg}^{-1}$ $\mathrm{C})$, the measured $\mathrm{P}: \mathrm{C}$ ratios were in the range of 39 to $88 \mu \mathrm{g} \mathrm{P} \mathrm{mg}^{-1} \mathrm{C}$ (mean $=63 \pm 4.2 \mu \mathrm{g} \mathrm{P} \mathrm{mg}^{-1} \mathrm{C}_{\text {; }}$ Fig. 8A), and the measured $\mathrm{N}: \mathrm{P}$ ratios were in the range of 0.8 to $1.8 \mathrm{mg} \mathrm{N} \mathrm{mg}^{-1} \mathrm{P}$ (mean $=1.2 \pm 0.10 \mathrm{mg}$ $\mathrm{N} \mathrm{mg}^{-1} \mathrm{P}$; Fig. 8B).

\section{C, $\mathbf{N}$ and $\mathbf{P}$ wastes released from salmon cages}

The release rates of $\mathrm{C}, \mathrm{N}$ and $\mathrm{P}$ wastes in different months from both cages (Fig. 9) showed similar patterns of variations as feed used and fish produced (Fig. 1), increasing with time to the highest values in September for Cage $\mathrm{S}$ and in June for Cage L. The estimates showed that the major $\mathrm{C}$ and $\mathrm{N}$ wastes from the 2 cages were respired $\mathrm{CO}_{2}$ and excreted DIN, respectively, whereas the major P waste was associated with particles. Therefore, higher proportions of feed $\mathrm{C}$ and $\mathrm{N}$ than of feed $\mathrm{P}$ were released as inorganic molecules, whereas the fractions of particulate $\mathrm{C}$ and $\mathrm{N}$ wastes were lower than the fraction of particulate $\mathrm{P}$.

Of the total input of feed $\mathrm{C}, \mathrm{N}$ and $\mathrm{P}$ for Cage S, $62 \%$ of $\mathrm{C}, 57 \%$ of $\mathrm{N}$ and $76 \%$ of $\mathrm{P}$ were lost to the environment. About $40 \%$ of feed $\mathrm{C}$ was respired as $\mathrm{CO}_{2}$, whereas $39 \%$ of feed $\mathrm{N}$ and $24 \%$ of feed P were excreted as DIN and DIP, respectively. About $19 \%$ of feed C, $15 \%$ of feed $\mathrm{N}$ and $44 \%$ of feed $\mathrm{P}$ were released as particles. Only about $3 \%$ of feed C, $3 \%$ of feed $\mathrm{N}$ and $8 \%$ of feed $\mathrm{P}$ were re-suspended from particles, forming DOC, DON and DOP, respectively (Fig. 9A,C,E). Similar values were found for Cage L (Fig. 9B,D,F).

The model predicted that $\mathrm{N}: \mathrm{C}, \mathrm{P}: \mathrm{C}$ and N:P ratios of faeces were $81 \mu \mathrm{g} \mathrm{N} \mathrm{mg}^{-1} \mathrm{C}, 42 \mu \mathrm{P} \mathrm{mg}^{-1} \mathrm{C}$ (Fig. 8A) and $1.9 \mathrm{mg} \mathrm{N} \mathrm{mg}^{-1} \mathrm{P}$ (Fig. 8B), respectively, and the ratios remained constant over time. There were no significant differences between the predicted and the measured $\mathrm{N}$ :C ratios of faeces ( $p>0.05)$, whereas the predicted $\mathrm{P}: \mathrm{C}$ ratio was significantly lower than the mean measured P:C ratio $(\mathrm{p}<0.05)$. The predicted $\mathrm{N}$ :P ratio was significantly higher than the mean measured N:P ratio $(\mathrm{p}<0.05)$ of faeces (Fig. $8 \mathrm{~B})$. The average DIN:DIP ratio was $10.5 \pm 0.03$ (data not shown), which was well above the Redfield ratio of 7.2.

\section{DISCUSSION}

\section{Release rates of $\mathbf{C}, \mathbf{N}$ and $P$ wastes}

Although salmon allocate a large fraction of feed into fish biomass, the major feed $\mathrm{C}, \mathrm{N}$ and $\mathrm{P}$ were lost

Table 4. Range of chemical content and mean chemical content in faeces samples from March to November 2009 (see Fig. 9 for the monthly chemical content for each cage), as well as regression coefficients for chemical content in faeces samples as a function of fish wet weight (WW; kg). DW: dry weight; DHA: docosahexaenoic acid; EPA: eicosapentaenoic acid; TFA: total fatty acids

\begin{tabular}{|c|c|c|c|c|c|c|}
\hline \multirow[t]{2}{*}{ Variable } & \multirow{2}{*}{$\begin{array}{c}\text { Content } \\
\left(\mathrm{mg} \mathrm{g}^{-1} \mathrm{DW}\right)\end{array}$} & \multirow{2}{*}{$\begin{array}{l}\text { Mean } \pm \text { SE } \\
\left(\mathrm{mg} \mathrm{g}^{-1} \mathrm{DW}\right)\end{array}$} & \multirow{2}{*}{ 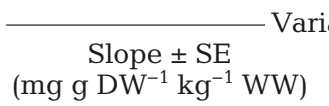 } & \multirow{2}{*}{$\begin{array}{c}\text { le versus wet } \\
Y_{0} \pm \mathrm{SE} \\
\left(\mathrm{mg} \mathrm{g}^{-1} \mathrm{DW}\right)\end{array}$} & \multirow[b]{2}{*}{$\mathrm{R}^{2}$} & \multirow[b]{2}{*}{$\mathrm{p}$} \\
\hline & & & & & & \\
\hline $\mathrm{C}$ & $312-448$ & $366 \pm 8.5$ & $9.9 \pm 4.8$ & $337 \pm 16$ & 0.14 & 0.05 \\
\hline $\mathrm{N}$ & $22-37$ & $27 \pm 1.5$ & $-0.7 \pm 0.78$ & $30 \pm 2.7$ & 0.03 & 0.38 \\
\hline $\mathrm{P}$ & $14-30$ & $23 \pm 1.3$ & $-0.5 \pm 1.0$ & $25 \pm 3.5$ & 0.01 & 0.62 \\
\hline Lipid & $64-89$ & $74 \pm 2.3$ & $-2.9 \pm 2.4$ & $82 \pm 7.4$ & 0.16 & 0.26 \\
\hline DHA & $1.0-4.0$ & $1.7 \pm 0.2$ & $-0.6 \pm 0.26$ & $3.4 \pm 0.80$ & 0.38 & 0.07 \\
\hline \multirow[t]{2}{*}{ EPA } & $0.5-1.6$ & $0.8 \pm 0.1$ & $-0.2 \pm 0.097$ & $1.4 \pm 0.30$ & 0.33 & 0.10 \\
\hline & $\begin{array}{c}\text { Content } \\
(\%)\end{array}$ & $\begin{array}{c}\text { Mean } \pm \text { SE } \\
(\%)\end{array}$ & $\begin{array}{c}\text { Slope } \pm \text { SE } \\
\left(\% \mathrm{~kg}^{-1} \mathrm{WW}\right)\end{array}$ & $\begin{array}{c}Y_{0} \pm \mathrm{SE} \\
(\%)\end{array}$ & & \\
\hline DHA $\%$ of TFA & $2.6-4.4$ & $3.3 \pm 0.2$ & $-1.0 \pm 0.42$ & $6.7 \pm 1.3$ & 0.45 & 0.06 \\
\hline EPA \% of TFA & $1.0-3.5$ & $1.9 \pm 0.2$ & $-0.4 \pm 0.24$ & $3.1 \pm 0.74$ & 0.24 & 0.17 \\
\hline
\end{tabular}



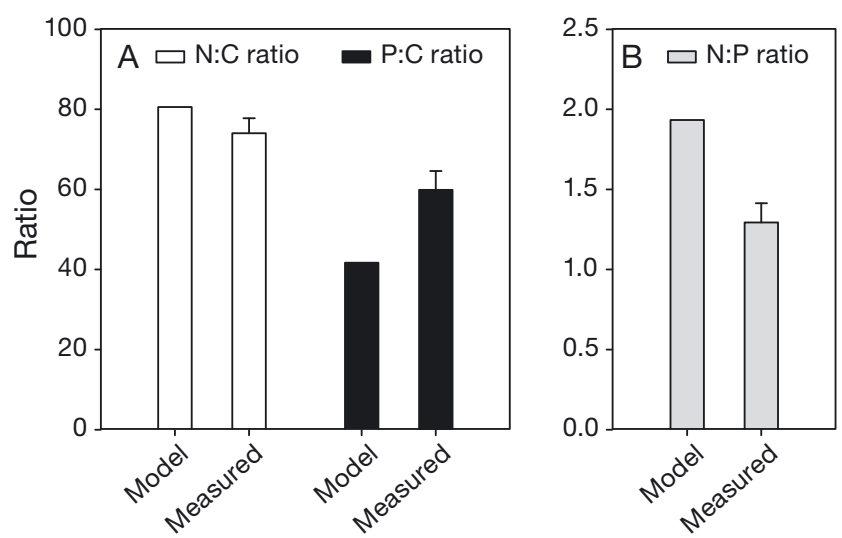

Fig. 8. Comparison between predicted and measured N:C $\left(\mu \mathrm{g} \mathrm{N} \mathrm{mg}{ }^{-1} \mathrm{C}\right), \mathrm{P}: \mathrm{C}\left(\mu \mathrm{g} \mathrm{P} \mathrm{mg}^{-1} \mathrm{C}\right)$ and $\mathrm{N}: \mathrm{P}\left(\mathrm{mg} \mathrm{N} \mathrm{mg}^{-1} \mathrm{P}\right)$ ratios of faeces samples collected from 2 salmon cages

into the surrounding environment, and the monthly release rates of wastes primarily depended on the feed used and fish produced. The monthly release rates of biogenic wastes from the 2 cages changed significantly over time, suggesting that the monthly/ seasonal variation in the release rates of wastes throughout must be considered when evaluating the environmental effects of fish farming.

Wang et al. (2012) found that $70 \%$ of feed C was released into the environment, of which $48 \%$ of feed $\mathrm{C}$ was respired by fish. These values were slightly higher than those found for a specific salmon farm in central Norway using revised coefficients in the present study. Consequently, $\mathrm{GE}_{\mathrm{C}}$, which expresses the biological efficiency of the production per feed consumed for C, was higher in the present study $(40 \%)$ than the value (31\%) reported by Wang et al. (2012).

Our predictions of release rates of wastes were lower compared with early values published by Perez (2002), who reported that $87 \%$ of feed C was lost to the environment, of which $45 \%$ was released as $\mathrm{CO}_{2}$ and $42 \%$ was released as POC. This was likely due to the lower feed losses in the present than those in the study by Perez (2002), who assumed that $10 \%$ of the total feed input was lost as uneaten feed.

In recent studies of feeding assisted by modern technology, feed losses were found to be below $5 \%$ of the input (Cromey et al. 2002, Bureau et al. 2003, Reid et al. 2009). Feed losses in modern salmon aquaculture, using camera-assisted feeding control and acoustic registration of lost feed pellets, are small compared with the supply of feed, and there is probably limited economic and environmental improvement with further reduction of the feed loss. Therefore, a feed loss rate of $3 \%$ has been assumed in the present study, as suggested by Cromey et al. (2002), Reid et al. (2009) and Wang et al. (2012).
The results showed that $57 \%$ of feed $\mathrm{N}$ was released into the environment, which is equivalent to $35 \mathrm{~kg} \mathrm{~N}$ per tonne of salmon produced. A high fraction of feed $\mathrm{N}(39 \%)$ was lost as DIN, mainly as ammonium and urea, which are readily assimilated by macroalgae and phytoplankton. The estimated $\mathrm{N}$ release rate found in the present study was slightly lower than the value found $(62 \%)$ for Norwegian salmon aquaculture (Wang et al. 2012), and was also lower than values found in previous studies (Hall et al. 1992, Enell 1995, Davies 2000, Islam 2005).

The lower $\mathrm{N}$ release rate obtained in the present study was a result of the lower $\mathrm{N}$ content (5.8\% of dry weight) of the feed that was specifically measured and used in the present study, whereas the $\mathrm{N}$ content of feed was previously reported to be in the range of 6.5 to $9.4 \%$ of dry weight (Hall et al. 1992, Enell 1995, Petersen et al. 2005, Mente et al. 2006). N is a proxy for the content of proteins in feed, and the lower $\mathrm{N}$ content of feed indicated lower protein content. The lipid content ( $39 \%$ of dry weight) was higher than the values reported in previous studies, ranging from around $20 \%$ in the 1980 s to $35 \%$ in recent years. Many studies have shown that the replacement of protein by lipid in feed resulted in an increase of digestible energy, and consequently an increased protein $(\mathrm{N})$ retention efficiency, as well as a lower ammonia release rate (Johnsen et al. 1993, Einen \& Roem 1997, McGoogan \& Gatlin 1999). Our results confirmed the protein sparing of using non-protein energy sources to meet energy requirements, resulting in a decreased release rate of DIN wastes.

The retention efficiency of $\mathrm{P}$ by fish has been reported to be about $20 \%$ (Sugiura et al. 2006), a value that is very close to our estimate. Unlike $\mathrm{C}$ and $\mathrm{N}$, a major proportion of feed $\mathrm{P}$ was released as particles because of the low $\mathrm{P}$ digestibility in feed. Foodstuffs of animal origin may contain a high $\mathrm{P}$ content, of which a main part is in inorganic form and is apparently highly digestible to fish. In contrast, phytate-P from plant ingredients is almost indigestible to fish (Hua \& Bureau 2006) because they do not produce the enzyme phytase (Cho \& Bureau 2001).

Our results showed a large proportion of feed $\mathrm{P}$ (24-26\%) was released as DIP, indicating that the available dietary $\mathrm{P}$ exceeded the minimal $\mathrm{P}$ requirement by fish. The minimum dietary requirement of $P$ by Atlantic salmon $(60 \mathrm{~g})$ was reported to be $5.5 \mathrm{mg} P$ $\mathrm{g}^{-1}$ diet with an FCR of 1.1, which decreased as fish grew (Sugiura et al. 2000). The total P content of feed in the present study ranged from 6.4 to $10 \mathrm{mg} \mathrm{g}^{-1}$ dry weight (mean $=8.8 \pm 0.5 \mathrm{mg} \mathrm{g}^{-1}$ dry weight), which was higher than fish requirements. Therefore, we 
Cage S
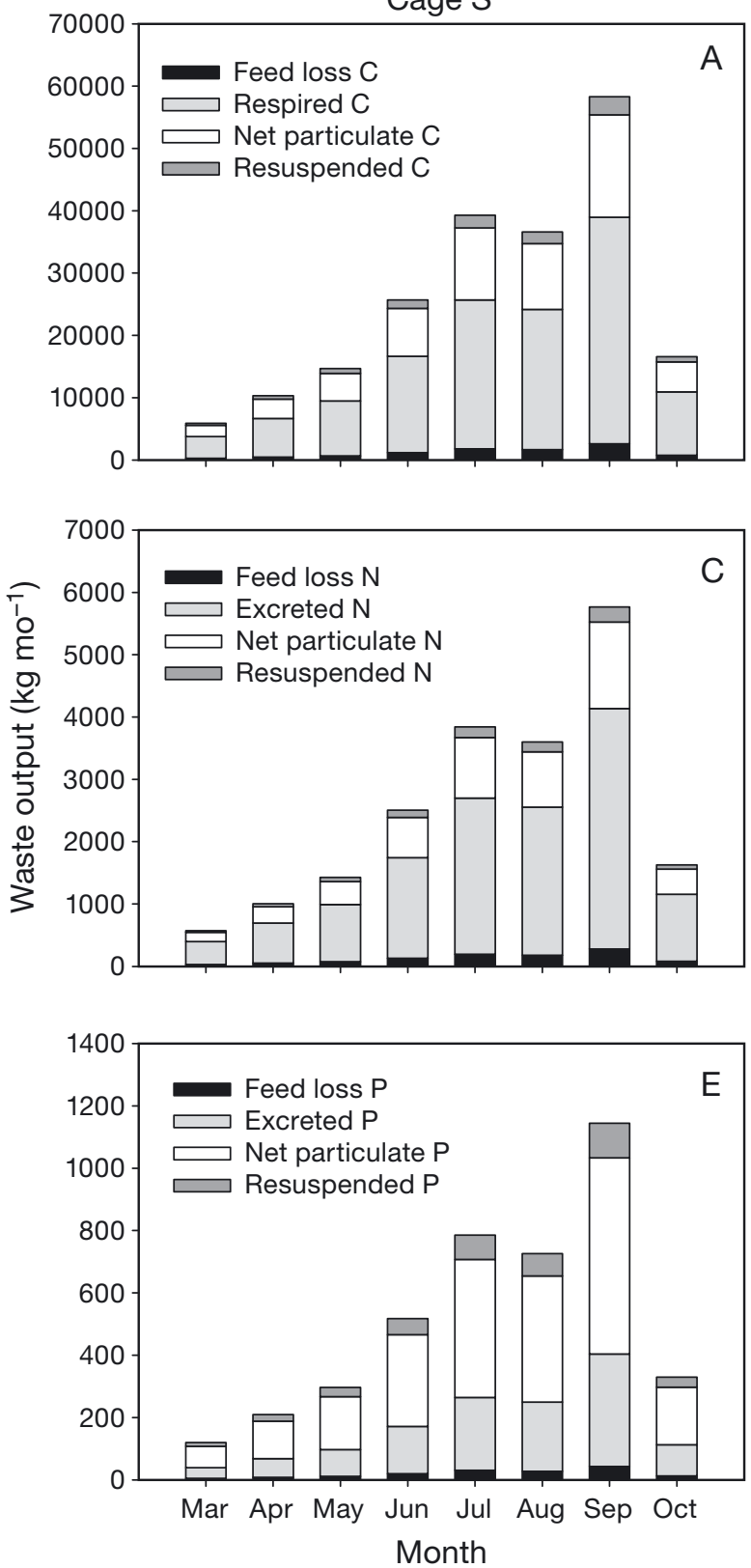

Cage L
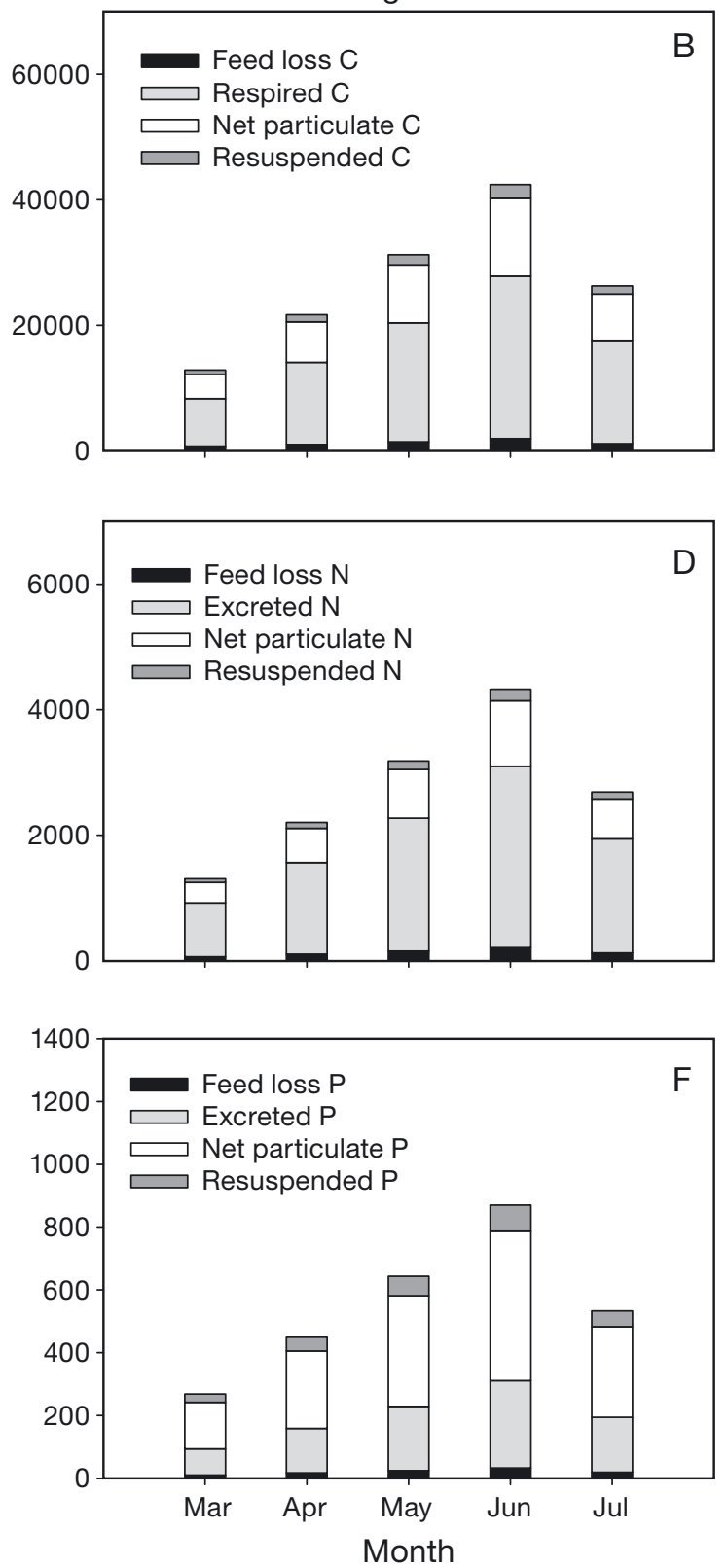

Fig. 9. Model estimates of different C, N and P waste outputs from Cage S (from March to October) and Cage L (from March to July) fish fed on commercial feed pellets. (A) C mass balance for Cage $S_{\text {; }}$ (B) C mass balance for Cage L; (C) $\mathrm{N}$ mass balance for Cage $S_{;}(D) N$ mass balance for Cage $L_{;}(E) P$ mass balance for Cage $S_{\text {; }}$ and $(F) P$ mass balance for Cage L. All values were based on dry weight

suggest that the total level of $\mathrm{P}$ in feed can be further reduced in order to reduce the release rate of $\mathrm{P}$ wastes.

\section{Nutritional values of faeces}

Our results showed that the mean $\mathrm{C}$ content per gram dry weight (Table 4) of faeces was $70 \%$ of that of feed (Table 2), while the $\mathrm{N}$ content of faeces was $46 \%$ of that of feed. The $\mathrm{N}$ :C ratio of salmon faeces was accordingly lower than that of feed, likely because of the high protein retention rate of the high-energy diet. However, the mean $\mathrm{P}$ content per gram dry weight of faeces was far higher than that of feed, suggesting that the main path of P loss was through faeces (Kibria et al. 1997). A high $\mathrm{P}$ content of faeces $(4 \%)$ has also 
been reported for Atlantic salmon by Kristiansen \& Hessen (1992) and for silver perch by Kibria et al. (1997). The total lipid, DHA and EPA contents of faeces were far lower than that of feed due to the efficient digestion of lipid, DHA and EPA. In the present study, the faeces samples were taken from the latter part of the hindgut where the absorption of nutrients was completed (Windell et al. 1978), and the faeces samples did not contain urine from fish; therefore, the chemical content of faeces in the present study was reliable.

The predicted N:C ratio of faeces fitted well with the measured value, whereas significant differences were found between the predicted and measured $\mathrm{P}: \mathrm{C}$ and $\mathrm{N}: \mathrm{P}$ ratios. We used an $\mathrm{N}$ digestibility of $85 \%$, comparable to that of protein, in the calculations. This approach is fairly robust. The digestibility of protein is normally measured for all feed batches by the feed manufacturer, and $85 \pm 2 \%$ is a common range of variation in the declaration of protein digestibility of feed batches (Trygve Lea, Skretting AS, pers. comm.). The $\mathrm{C}$ digestibility in feed was assumed to be $80 \%$ in the present study, which was in agreement with Cheshuk et al. (2003) and Mente et al. (2006). If the digestibility of $\mathrm{C}$ and $\mathrm{N}$ in the model was the key variable that caused the differences between measurements and predictions, the $\mathrm{C}$ digestibility would need to be increased from 80 to $85 \%$ and the $\mathrm{N}$ digestibility from 85 to $90 \%$ at the same time to obtain similar predicted and measured N:C, P:C and N:P ratios. Such an increase in the digestibility of $\mathrm{C}$ and $\mathrm{N}$ will not cause major differences in model predictions (Wang et al. 2012).

The assumption of $50 \%$ of $\mathrm{P}$ digestibility in feed was much more uncertain than the assumptions made for $\mathrm{C}$ and $\mathrm{N}$, mostly because of the high diversity of $\mathrm{P}$ components in feed (Cho \& Bureau 2001, Hua \& Bureau 2006). If the differences between the predicted and the measured values were assumed to be caused by an inappropriate input $\mathrm{P}$ digestibility in the model and if we force the predicted $\mathrm{N}: \mathrm{P}$ ratio to fit the mean measured value, the input $\mathrm{P}$ digestibility should be decreased from 50 to $30 \%$. This would have resulted in a significant increase in the predicted release of percentage faecal $\mathrm{P}$ of the total $\mathrm{P}$ waste, and of DOP wastes released from faecal particles, as well as a decrease in percentage DIP waste of the total $\mathrm{P}$ waste, as discussed by Wang et al. (2012). We suggest that the $\mathrm{P}$ digestibility of feed may be as low as $30 \%$, but further information is needed to reach conclusions on this point.

\section{Potential of food availability for IMTA}

Our results showed that the $\mathrm{C}, \mathrm{N}$, total lipid, DHA and EPA contents per gram dry weight (Table 2) of feed were higher than that of faeces (Table 4). Feed wastes constituted only $3 \%$ of the feed used in modern salmon aquaculture and the major solid wastes were faecal particles. The N:C (62-99 $\left.\mu \mathrm{g} \mathrm{N} \mathrm{mg}^{-1} \mathrm{C}\right)$ and N:P (0.8-1.8 $\mathrm{mg} \mathrm{N} \mathrm{mg}^{-1} \mathrm{P}$ ) ratios of salmon faeces were lower than those of some phytoplankton species, whereas the P:C ratios of salmon faeces were far higher than that of some phytoplankton (Table 5). The lipid content of salmon faeces (64-89 $\mathrm{mg} \mathrm{g}^{-1}$ dry weight) was in the range of that of some marine diatoms (24-278 $\mathrm{mg} \mathrm{g}^{-1}$ dry weight) (Renaud et al. 1994, Liang et al. 2000), which dominate the spring bloom in the Trondheimfjord (Sakshaug \& Myklestad 1973). Moreover, the DHA and EPA contents of salmon faeces were similar to the levels of diatoms and Prymnesiophyceae (Isochrysis galbana), respectively (Reitan et al. 1994, Renaud et al. 1994, Liang et al. 2000). Our results indicated that salmon faeces have a poorer nutritional value than salmon feed and some microalgae, but that this particular food source still can be adequate to support the growth of bivalves in an IMTA system. The bivalves may benefit more from salmon feed and faeces in nutrient-limited areas than in areas with high phytoplankton biomass (Handå et al. 2012).

Only a small portion of salmon farm wastes can be incorporated by blue mussels (Wang et al. 2012), and the major salmon feed and faecal particles sink and accumulate in sediments near cages (Elberizon \& Kelly 1998). These wastes may be better exploited by deposit-feeding organisms such as sea cucumbers (Uthicke 1999, Michio et al. 2003), which have exhibited higher yields when co-cultured with salmon (Ahlgren 1998, Paltzat et al. 2008). Our results suggested that both salmon feed and faeces are nutritionally adequate for filter and deposit feeding species co-cultured with salmon. Although some of the nutritional values are lower than salmon feed and some phytoplankton species, we suggest that salmon faeces can still contribute to the growth of cocultured organic extractive species such as filter and deposit feeders in an IMTA system.

Acknowledgements. This work forms part of the Research Council of Norway project no.173527 (INTEGRATE). We are grateful to the Norwegian Research Council and the China Scholarship Council for the financial support. We thank Lerøy Midnor for allowing access to their salmon farm at Sandstad and for providing data on monthly fish production, feed use and environmental conditions. Thanks also to Keshuai Li at the Norwegian University of Science and Technology for his fatty acid analysis. 


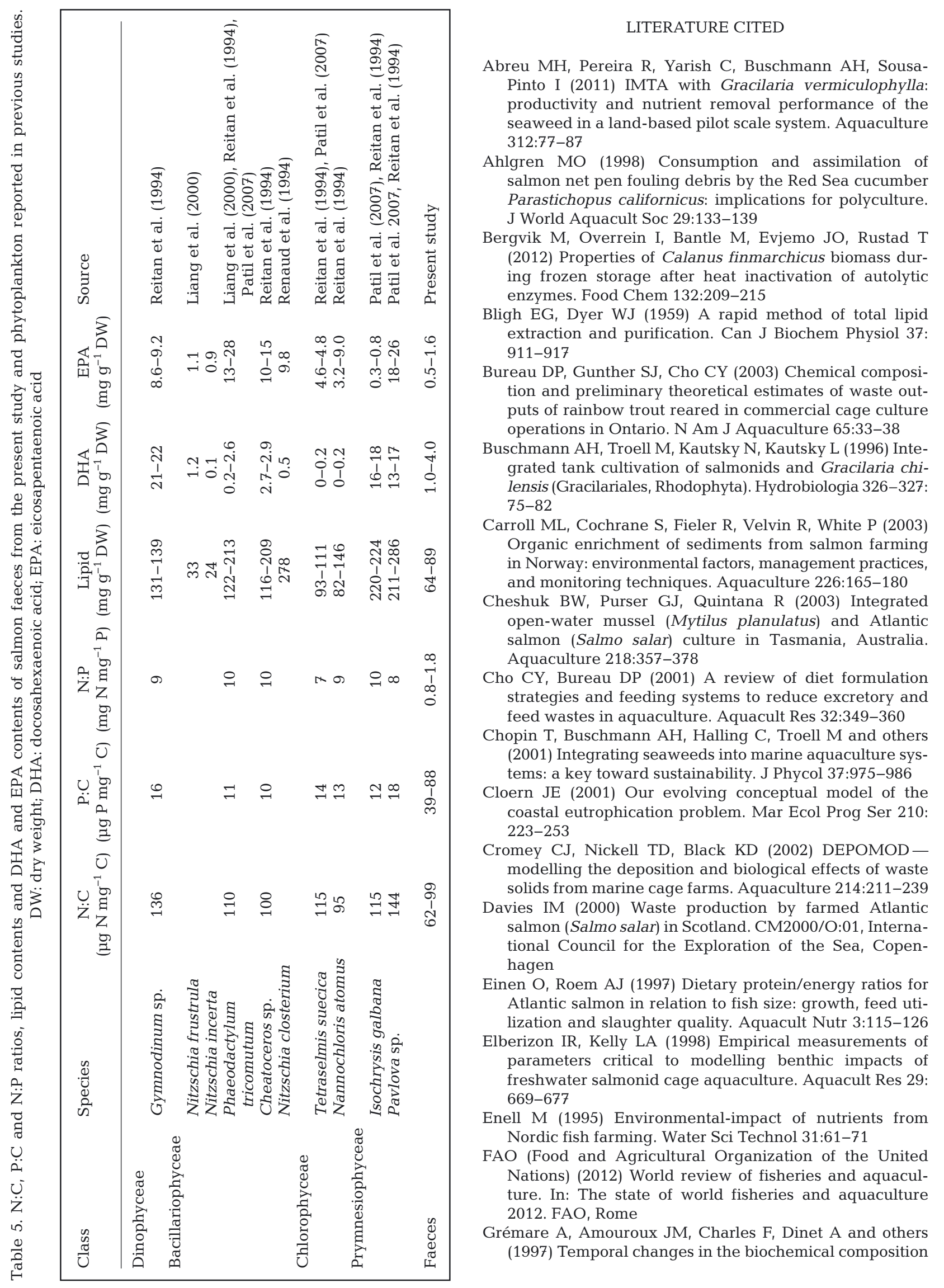


and nutritional value of the particulate organic matter available to surface deposit-feeders: a two year study. Mar Ecol Prog Ser 150:195-206

Hall POJ, Anderson LG, Holby O, Kollberg S, Samuelsson MO (1990) Chemical fluxes and mass balances in a marine fish cage farm. I. Carbon. Mar Ecol Prog Ser 61:61-73

Hall POJ, Holby O, Kollberg S, Samuelsson M (1992) Chemical fluxes and mass balances in a marine fish cage farm. IV. Nitrogen. Mar Ecol Prog Ser 89:81-91

Handå A (2012) Cultivation of mussels (Mytilus edulis): feed requirements, storage and integration with salmon (Salmo salar) farming. PhD thesis, Norwegian University of Science and Technology, Trondheim

Handå A, Min H, Wang X, Broch OJ, Reitan KI, Reinertsen $\mathrm{H}$, Olsen Y (2012) Incorporation of fish feed and growth of blue mussels (Mytilus edulis) in close proximity to salmon (Salmo salar) aquaculture: implications for integrated multi-trophic aquaculture in Norwegian coastal waters. Aquaculture 356-357:328-341

Hansen HP, Koroleff F (1999) Determination of nutrients. In: Grasshoff K, Kremling K, Ehrhardt M (eds) Methods of seawater analysis. Wiley-VCH Verlag, Weinheim, p $159-228$

Hua K, Bureau DP (2006) Modelling digestible phosphorus content of salmonid fish feeds. Aquaculture 254:455-465

Islam MS (2005) Nitrogen and phosphorus budget in coastal and marine cage aquaculture and impacts of effluent loading on ecosystem: review and analysis towards model development. Mar Pollut Bull 50:48-61

Johnsen F, Hillestad M, Austreng E (1993) High-energy diets for Atlantic salmon - effects on pollution. In: Kaushik SJ, Luquet P (eds) Fish nutrition in practice. Proc 4 th Int Symp Fish Nutr Feeding 61:391-401

Kibria G, Nugegoda D, Fairclough R, Lam P (1997) The nutrient content and the release of nutrients from fish food and faeces. Hydrobiologia 357:165-171

Kristiansen G, Hessen DO (1992) Nitrogen and phosphorus excretion from the noble crayfish, Astacus astacus L., in relation to food type and temperature. Aquaculture 102: 245-264

> Kutti T, Hansen PK, Ervik A, Hoisaeter T, Johannessen P (2007) Effects of organic effluents from a salmon farm on a fjord system. II. Temporal and spatial patterns in infauna community composition. Aquaculture 262:355-366

Kutti T, Ervik A, Hoisaeter T (2008) Effects of organic effluents from a salmon farm on a fjord system. III. Linking deposition rates of organic matter and benthic productivity. Aquaculture 282:47-53

Liang Y, Mai K, Sun S (2000) Total lipid and fatty acid composition of eight strains of marine diatoms. Chin J Oceanology Limnol 18:345-349

MacDonald BA, Robinson SMC, Barrington KA (2011) Feeding activity of mussels (Mytilus edulis) held in the field at an integrated multi-trophic aquaculture (IMTA) site (Salmo salar) and exposed to fish food in the laboratory. Aquaculture 314:244-251

Mantzavrakos E, Kornaros M, Lyberatos G, Kaspiris P (2005) Impacts of a marine fish farm in Argolikos Gulf on the water column and the sediment. Proc Int Conf Env Sci Vol A:A928-A933

> Marinho-Soriano E, Nunes SO, Carneiro MAA, Pereira DC (2009) Nutrients' removal from aquaculture wastewater using the macroalgae Gracilaria birdiae. Biomass Bioenergy 33:327-331

McGoogan BB, Gatlin DM (1999) Dietary manipulations affecting growth and nitrogenous waste production of red drum, Sciaenops ocellatus I. Effects of dietary protein and energy levels. Aquaculture 178:333-348

Mente E, Pierce GJ, Santos MB, Neofitou C (2006) Effect of feed and feeding in the culture of salmonids on the marine aquatic environment: a synthesis for European aquaculture. Aquacult Int 14:499-522

> Merceron M, Kempf M, Bentley D, Gaffet JD, Le Grand J, Lamort-Datin L (2002) Environmental impact of a salmonid farm on a well flushed marine site. I. Current and water quality. J Appl Ichthyol 18:40-50

Metcalfe LD, Schmitz AA, Pelka JR (1966) Rapid preparation of fatty acid esters from lipids for gas chromatographic analysis. Anal Chem 38:514-515

Michio K, Kengo K, Yasunori K, Hitoshi M, Takayuki Y, Hideaki Y, Hiroshi S (2003) Effects of deposit feeder Stichopus japonicus on algal bloom and organic matter contents of bottom sediments of the enclosed sea. Mar Pollut Bull 47:118-125

Moulton CR (1923) Age and chemical development in mammals. J Biol Chem 57:79-97

Paltzat DL, Pearce CM, Barnes PA, McKinley RS (2008) Growth and production of California sea cucumbers (Parastichopus californicus Stimpson) co-cultured with suspended Pacific oysters (Crassostrea gigas Thunberg). Aquaculture 275:124-137

Patil V, Källqvist T, Olsen E, Vogt G, Gislerød H (2007) Fatty acid composition of 12 microalgae for possible use in aquaculture feed. Aquacult Int 15:1-9

Perez V, Källqvist T, Olsen E, Vogt G, Gislerød H (2007) Fatty acid composition of 12 microalgae for possible use in aquaculture feed. Aquacult Int 15:1-90

> Perez O (2002) Geographical Information Systems (GIS) as a simple tool to aid modelling of particulate waste distribution at marine fish cage sites. Estuar Coast Shelf Sci 54: 761-768

Petersen SA, Sutherland RF, Higgs D (2005) Physical and chemical characterization of salmonid feed pellets. Can Data Rep Fish Aquat Sci 1159:1-16

> Petrell RJ, Alie SY (1996) Integrated cultivation of salmonids and seaweeds in open systems. Hydrobiologia 326-327: $67-73$

> Porrello S, Lenzi M, Persia E, Tomassetti P, Finoia MG (2003) Reduction of aquaculture wastewater eutrophication by phytotreatment ponds system. I. Dissolved and particulate nitrogen and phosphorus. Aquaculture 219:515-529

Reid GK, Liutkus M, Robinson SMC, Chopin TR and others (2009) A review of the biophysical properties of salmonid faeces: implications for aquaculture waste dispersal models and integrated multi-trophic aquaculture. Aquacult Res 40:257-273

Reitan KI, Rainuzzo JR, Olsen Y (1994) Effect of nutrient limitation on fatty acid and lipid content of marine microalgae. J Phycol 30:972-979

> Ren Y, Dong S, Qin C, Wang F, Tian X, Gao Q (2012) Ecological effects of co-culturing sea cucumber Apostichopus japonicus (Selenka) with scallop Chlamys farreri in earthen ponds. Chin J Oceanology Limnol 30:71-79

Renaud S, Parry D, Thinh LV (1994) Microalgae for use in tropical aquaculture I: Gross chemical and fatty acid composition of twelve species of microalgae from the Northern Territory, Australia. J Appl Phycol 6:337-345

Sakshaug E, Myklestad S (1973) Studies on the phytoplankton ecology of the Trondheimsfjord. III. Dynamics of phytoplankton blooms in relation to environmental fac- 
tors, bioassay experiments and parameters for the physiological state of the populations. J Exp Mar Biol Ecol 11: $157-188$

Skogen MD, Eknes M, Asplin LC, Sandvik AD (2009) Modelling the environmental effects of fish farming in a Norwegian fjord. Aquaculture 298:70-75

Stigebrandt A, Aure J, Ervik A, Hansen PK (2004) Regulating the local environmental impact of intensive marine fish farming. III. A model for estimation of the holding capacity in the modelling-ongrowing fish farm-monitoring system. Aquaculture 234:239-261

Sugiura SH, Dong FM, Hardy RW (2000) A new approach to estimating the minimum dietary requirement of phosphorus for large rainbow trout based on nonfecal excretions of phosphorus and nitrogen. J Nutr 130:865-872

Sugiura SH, Marchant DD, Kelsey K, Wiggins T, Ferraris RP (2006) Effluent profile of commercially used lowphosphorus fish feeds. Environ Pollut 140:95-101

Troell M, Norberg J (1998) Modelling output and retention of suspended solids in an integrated salmon-mussel cul-

Editorial responsibility: Kenneth Black, Oban, UK ture. Ecol Modell 110:65-77

Uthicke S (1999) Sediment bioturbation and impact of feeding activity of Holothuria (Halodeima) atra and Stichopus chloronotus, two sediment feeding holothurians, at Lizard Island, Great Barrier Reef. Bull Mar Sci 64:129-141

Wang X, Olsen LM, Reitan KI, Olsen Y (2012) Discharge of nutrient wastes from salmon farms: environmental effects, and potential for integrated multi-trophic aquaculture. Aquacult Environ Interact 2:267-283

- Whitmarsh DJ, Cook EJ, Black KD (2006) Searching for sustainability in aquaculture: an investigation into the economic prospects for an integrated salmon-mussel production system. Mar Policy 30:293-298

Windell JT, Foltz JW, Sarokon JA (1978) Methods of faecal collection and nutrient leaching in digestibility studies. Prog Fish-Cult 40:51-55

Zhou Y, Yang H, Hu H, Liu Y and others (2006) Bioremediation potential of the macroalga Gracilaria lemaneiformis (Rhodophyta) integrated into fed fish culture in coastal waters of north China. Aquaculture 252:264-276

Submitted: February 22, 2013; Accepted: June 10, 2013

Proofs received from author(s): July 17, 2013 